\title{
Analysis of the Impact of Inflationary Processes on the Functioning of Second-tier Banks in the Regions of Kazakhstan
}

\author{
Zhanara Tastemirova \\ Institute of Economics and law \\ A. Baitursynov Kostanay regional University \\ Kostanay, Republic of Kazakhstan \\ bektau@mail.ru \\ Aruzhan Baranbayeva \\ Institute of Economics and law \\ A. Baitursynov Kostanay regional University \\ Kostanay, Republic of Kazakhstan \\ bektau@mail.ru
}

\author{
Aizhan Kurmangaliyeva \\ Institute of Economics and law \\ A. Baitursynov Kostanay regional University \\ Kostanay, Republic of Kazakhstan \\ bektau@mail.ru \\ Yersultan Kanatov \\ Institute of Economics and law \\ A. Baitursynov Kostanay regional University \\ Kostanay, Republic of Kazakhstan \\ bektau@mail.ru
}

\begin{abstract}
The manifestation of inflationary processes is directly related to the structure and dynamics of the money supply, as well as its main flows. The growth of the money supply and the velocity and direction of movement of its main streams in the most part due to the functioning of the banking sector as a basic element of financial and credit system of the Republic of Kazakhstan. Commercial banks are not only the main channels for servicing the movement of the money supply and its redistribution, but also the creators of money in the economy. In this regard, the analysis of the impact of inflation on the activities of commercial banks, as well as the assessment of its consequences, both negative and positive, becomes relevant. The article studies the impact of inflationary processes on the functioning of second-tier banks in the regions of Kazakhstan according to the data of JSC "Eurasian Bank". Analysis of the financial statements of JSC "Eurasian Bank", calculated the structure of the share of the Bank's assets, liabilities and capital, considered the Bank's liabilities and capital. Interest rates on loans and deposits of JSC "Eurasian Bank"are analyzed. It was determined that in order to neutralize the influence of inflationary processes on the functioning, banks need to develop a long-term strategy and tactics for conducting credit policy.
\end{abstract}

Keywords-commercial bank, inflation, credit policy, loan portfolio, capitalization, net investment, cash, bank assets and liabilities.

\section{INTRODUCTION}

Today, in the current market environment, the inflationary phenomenon is considered as a complex multidimensional process caused by an imbalance in the reproduction system in all market segments. Violations of these imbalances are negative for all participants in the market economy and become a complex acute problem that cannot be resolved automatically or in the distant future. Such complex tasks at the macroeconomic level are always relevant, and almost all countries of the world economy are dealing with these problematic inflationary processes.

The process of reducing the value of the money supply is accompanied by a reduction in their purchasing power of money associated with price growth, a crisis in commodity markets, a deficit, a drop in the quality of services and goods provided, and surpluses in money channels that exceed the demand for turnover $[2,4,5,20-21]$.

At the same time, inflation negatively affects the formation and redistribution of national income across various segments of the economy, by corporate structures, households, and the state, i.e. by all economic agents.

The mechanism of visual manifestation of the inflation process is interrelated with the mass of money, its content, main flows and volume dynamics. The speed of turnover, the increment of the money supply and the direction of cash flows are mediated by the banking system, which is the basis of the state's credit system [3,7-9,14-17].

The relationship between inflation in the economy, as an indicator of macroeconomics, and the banking system has not been sufficiently studied, and has little coverage in the economic literature. These factors determined the importance of the work and the need to analyze the impact of inflationary processes on commercial banks.

\section{METHODS}

The work used the following research methods: generalization, comparative analysis of methods for ensuring financial stability and security of a commercial bank, analysis of inflationary processes on the functioning of banks, time series, economic groupings, conceptual modeling of the parameters of functioning of second-tier banks in the regions of Kazakhstan.

\section{MAIN PART}

Eurasian Bank was established in December 1994 as a joint-stock Bank with an authorized capital of 95.6 million tenge. Full name joint-Stock company "Eurasian Bank "(Hereinafter referred to as JSC "Eurasian Bank"). 
According to the Charter of JSC "Eurasian Bank", the sequence of implementation of the competence of management and Executive bodies is presented within the organizational structure. The organizational structure of the Bank is shown in figure 1. At the end of 2018, the Bank under study is one of the "trillionaires" banks, having increased its assets from 978.4 billion tenge in $2017 \mathrm{y}$. to 1,120 trillion tenge in 2018 y. Net income received by the Bank in 2018 increased by 7.08 billion tenge compared to the previous year and amounted to 11.451 billion tenge.

According to the results of a study by the National Bank of Kazakhstan in 2017, inflation in Kazakhstan was determined at the level of $7.11 \%$. this indicator accounts for half of the target corridor of $6-8 \%$. In more detail, the inflationary processes for 2018-2019 y. are shown in figure 2 .

So the figure shows that in 2018 , the annual inflation rate shows a decrease in the inflation rate to $6 \%$, and in 2019 , we see an increase in inflation, but this indicator does not exceed the target corridor. Thus, the reduction of external inflationary pressure, regulation of the situation on the currency market and the trend to consolidate the stability of the tenge during the year against the background of positive dynamics of circumstances on world commodity markets, the stability of prices for basic products on foreign agricultural markets contributed to the delay of inflationary phenomena. The biggest drop in inflation was hindered by a prolonged price shock in the energy market.

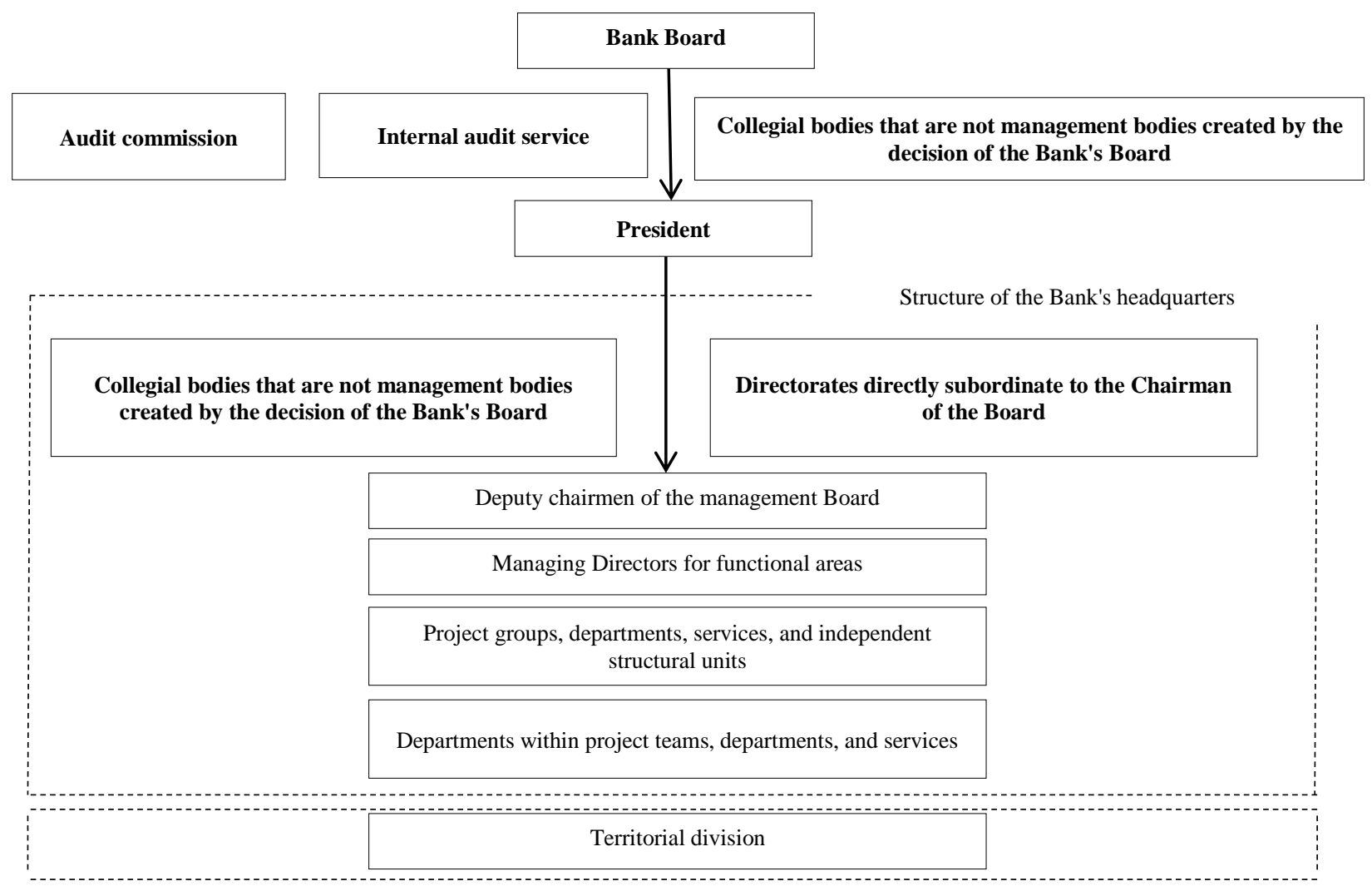

Fig.1. Organizational structure 


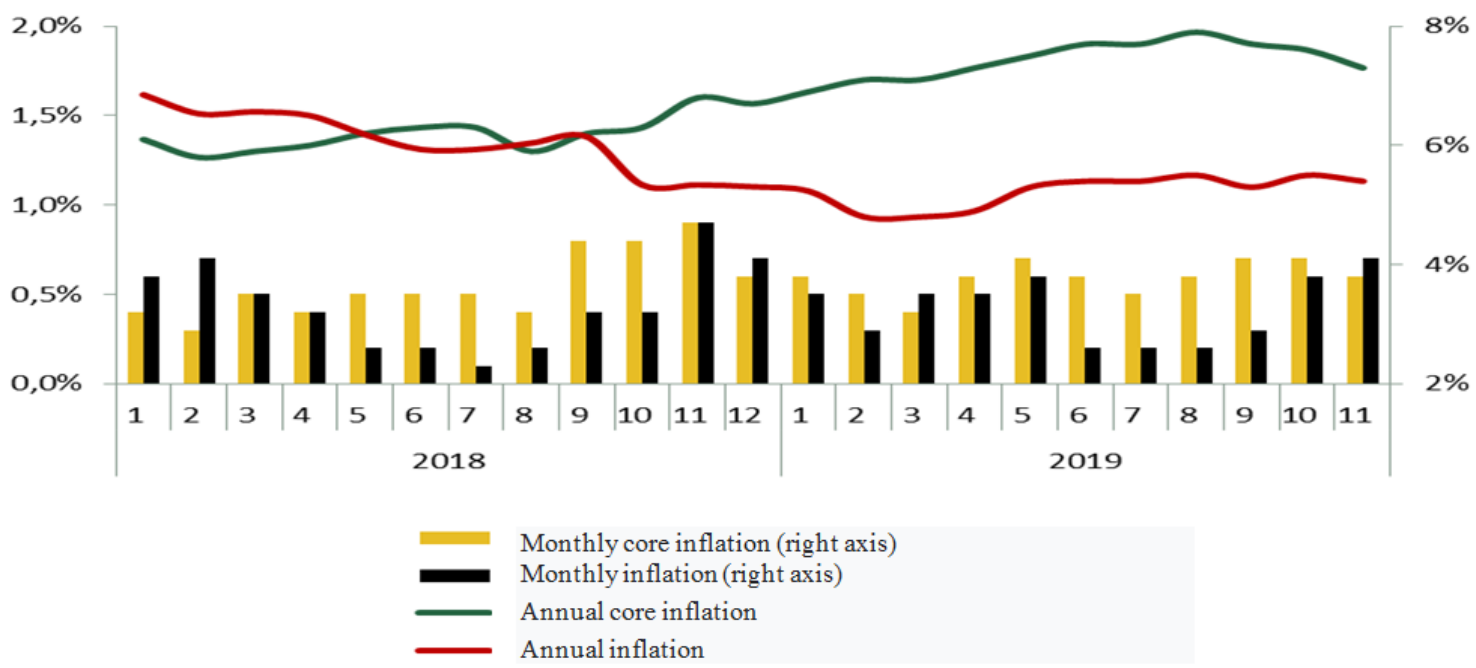

Fig.2. The rate of inflation in 2018-2019

Let's look at the effects of inflation on the financial results of JSC "Eurasian Bank". to do this, we will analyze assets and liabilities (see Table 1).

TABLE I. ANALYSIS OF ASSETS OF FINANCIAL STATEMENTS, JSC "EURASIAN BANK", BILLION TENGE

\begin{tabular}{|c|c|c|c|c|c|c|c|c|c|}
\hline Articles & $2017 \mathrm{y}$. & 2018 y. & $2019 y$. & \multicolumn{2}{|c|}{ Change } & $2017 \mathrm{y}$. & $2018 y$ & 2019 y. & \multirow{3}{*}{$\begin{array}{c}\begin{array}{c}\text { Ed. for } 3 \\
\text { years, \% }\end{array} \\
1,62\end{array}$} \\
\hline Assets & \multicolumn{3}{|c|}{ billion tenge } & aabs. & $\%$ & & fic weig & & \\
\hline Cash and cash equivalents & 109,32 & 153,6 & 138,52 & 29,20 & 26,71 & 10,9 & 15,7 & 12,5 & \\
\hline Financial instruments at fair value & 122,28 & 0,09 & 1,07 & $-121,2$ & $-99,1$ & 12,2 & 0,01 & 0,10 & $-12,1$ \\
\hline Financial asset & 3,00 & 50,38 & 173,18 & 170,2 & 5675,5 & 0,30 & 5,16 & 15,6 & 15,3 \\
\hline Bank accounts and deposits & 3,74 & 3,64 & 5,01 & 1,27 & 33,92 & 0,37 & 0,37 & 0,45 & 0,08 \\
\hline Loans and advances to customers & 696,45 & 614,4 & 638,01 & $-58,4$ & $-8,39$ & 69,3 & 62,9 & 57,6 & $-11,7$ \\
\hline $\begin{array}{l}\text { Investments carried at amortised } \\
\text { cost }\end{array}$ & 23,94 & 124,9 & 114,45 & 90,52 & 378,1 & 2,38 & 12,8 & 10,3 & 7,95 \\
\hline Current tax asset & 3,49 & 1,04 & 0,52 & $-2,98$ & $-85,2$ & 0,35 & 0,11 & 0,05 & $-0,30$ \\
\hline Fixed assets and intangible assets & 25,12 & 22,03 & 20,53 & $-4,59$ & $-18,3$ & 2,50 & 2,25 & 1,85 & $-0,65$ \\
\hline Deferred tax asset & & 0,00 & 0,22 & 0,22 & - & 0,00 & 0,00 & 0,02 & 0,02 \\
\hline Other assets & 17,93 & 6,92 & 16,77 & $-1,16$ & $-6,46$ & 1,78 & 0,71 & 1,51 & $-0,27$ \\
\hline Total assets & 1005,3 & 977,0 & 1108,3 & 103,0 & 10,25 & 100 & 100 & 100 & 0,00 \\
\hline
\end{tabular}

Results the consequences of inflationary processes affect the financial condition of the enterprise, reducing the real volume of the Bank's assets, reducing finances due to the depreciation of the resources attracted by them, regardless of their nominal growth.

The analysis of the Bank's assets for the study period from $2017 \mathrm{y}$. to $2019 \mathrm{y}$. indicates an increase in assets by $10.25 \%$ or 103.0 billion tenge. This increase in assets, primarily related to increased cash and short-term highly liquid investments 29,20 billion or $26,71 \%$, financial assets 170,2 billion or 56,76 times, investments carried at amortised cost 378,1 billion or $2.4 \%$ of deposits 1.27 billion or $33,92 \%$, etc.

In the structure of assets during the entire analyzed period, a significant share is taken up by loans issued to customers from the total amount of the Bank's assets, and the smallest share is accounted for by accounts and deposits with the Bank (see figure 3 ). 


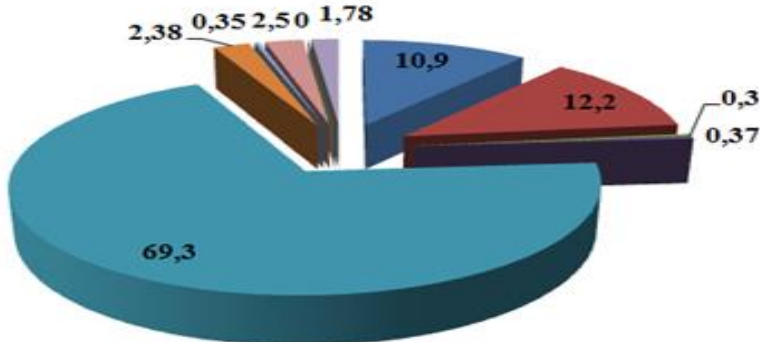

2017 y.

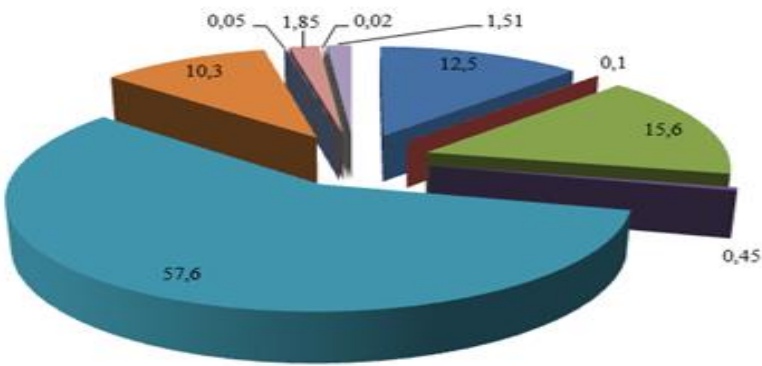

2019 y.

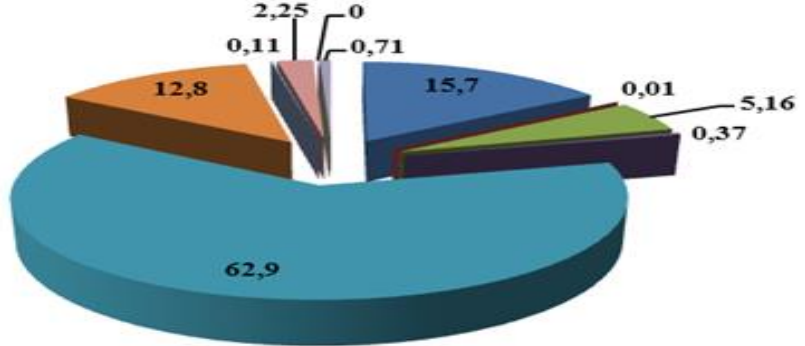

2018 y.

- Cash and cash equivalents

- Financial instrum ents measured at fair value

= Financial assets carried at fair value

$=\mathrm{B}$ ank accounts and deposits

= L oans to customers

$=$ Investments carried at amortized cost

= Current tax asset

= Fixed assets and intangible assets

$=$ Deferred tax assets

= Other assets

Fig.3. The Structure of the proportion of assets of JSC "Eurasian Bank"

Also it should be noted that in the intervening period, a decrease in current tax asset of 2.98 billion or 85.2 percent, fixed assets and intangible assets decreased by 4.59 billion, or $18.3 \%$, issued customer credits also decreased to 58.4 billion or $8.39 \%$.
Consider the analysis of the balance sheet items as liabilities and capital of JSC "Eurasian Bank" shown in table 2.

TABLE II. ANALYSIS OF LIABILITIES AND CAPITAL OF FINANCIAL STATEMENTS, JSC "EURASIAN BANK", BILLION TENGE

\begin{tabular}{|c|c|c|c|c|c|c|c|c|c|}
\hline \multirow{2}{*}{$\begin{array}{l}\text { Articles } \\
\text { Commitments }\end{array}$} & $2017 \mathrm{y}$ & 2018 y. & 2019 y. & \multicolumn{2}{|c|}{ Change } & $\begin{array}{c}2017 \\
\text { y. }\end{array}$ & $\begin{array}{c}2018 \\
\text { y. }\end{array}$ & $\begin{array}{c}2019 \\
\text { y. }\end{array}$ & \multirow{2}{*}{$\begin{array}{l}\text { Ed. For } 3 \\
\text { years, \% }\end{array}$} \\
\hline & \multicolumn{3}{|c|}{ billion tenge } & aabs. & $\%$ & \multicolumn{3}{|c|}{ Specific weight, \% } & \\
\hline Financial instruments at fair value & 0,01 & 0,02 & 0,00 & $-0,01$ & -100 & 0,00 & 0,00 & 0,00 & 0,00 \\
\hline Deposits and Bank accounts & 6,69 & 0,15 & 0,47 & $-6,22$ & $-92,9$ & 0,74 & 0,02 & 0,05 & $-0,69$ \\
\hline Accounts payable under repo transactions & 4,91 & 43,74 & 79,88 & 74,98 & 15,28 & 0,54 & 4,98 & 7,87 & 7,33 \\
\hline Current accounts and deposits of customers & 671,2 & 695,3 & 766,7 & 95,49 & 14,2 & 73,8 & 79,1 & 75,50 & 1,75 \\
\hline Subordinated debt securities issued & 23,75 & 67,96 & 70,74 & 46,99 & 198 & 2,61 & 7,73 & 6,97 & 4,36 \\
\hline Other funds raised & 55,14 & 37,99 & 35,48 & $-19,7$ & $-35,7$ & 6,06 & 4,32 & 3,49 & $-2,56$ \\
\hline Deferred tax liability & 2,31 & 3,77 & 3,87 & 1,56 & 67,7 & 0,25 & 0,43 & 0,38 & 0,13 \\
\hline Other liabilities & 16,62 & 9,78 & 14,63 & $-1,98$ & $-11,9$ & 1,83 & 1,11 & 1,44 & $-0,39$ \\
\hline Total liabilities & 910,0 & 879,3 & 1015,5 & 105,4 & 11,6 & 90,5 & 89,9 & 91,6 & 1,10 \\
\hline Share capital & 51,14 & 57,14 & 57,14 & 6,00 & 11,7 & 53,7 & 58,4 & 61,6 & 7,86 \\
\hline Share premium & 0,03 & 0,03 & 0,03 & 0,00 & 0,00 & 0,03 & 0,03 & 0,03 & 0,00 \\
\hline Provision for Gener & 8,23 & 8,23 & 8,23 & 0,00 & 0,00 & 8,65 & 8,42 & 8,87 & 0,22 \\
\hline Dynamic reserve & 7,59 & 7,59 & & $-7,59$ & -100 & 7,97 & 7,77 & 0,00 & $-7,97$ \\
\hline Revaluation reserve for financial assets & $-0,10$ & $-0,22$ & $-0,23$ & $-0,13$ & 122,8 & $-0,11$ & $-0,23$ & $-0,24$ & $-0,14$ \\
\hline $\begin{array}{l}\text { The accumulated reserve for translation to } \\
\text { presentation currency data }\end{array}$ & 1,74 & 2,25 & 1,88 & 0,14 & 8,20 & 1,82 & 2,31 & 2,03 & 0,20 \\
\hline Retained earnings & 26,61 & 22,75 & 25,78 & $-0,83$ & $-3,11$ & 27,9 & 23,3 & 27,77 & $-0,17$ \\
\hline All capital & 95,23 & 97,77 & 92,83 & $-2,41$ & $-2,53$ & 9,47 & 10,0 & 8,38 & $-1,10$ \\
\hline Total liabilities and equity & 1005,3 & 977,0 & 1108,3 & 103,0 & 10,25 & 100 & 100 & 100 & 0,00 \\
\hline
\end{tabular}

According to the information provided (see figure 8 ). we observe an increase in liabilities by 105.4 billion tenge or 11.6
$\%$ and a decrease in the Bank's capital by 2.41 billion tenge or $2.53 \%$. this situation was caused by a reduction in the 
Bank's deposits and accounts by $92.9 \%$ or 6.22 billion tenge. Changes in the indicators of debt securities issued decreased by 85.7 billion tenge or 66 . $\%$, financial instruments decreased by 0.01 billion tenge or $100 \%$, and other attracted funds decreased by 19.7 billion tenge or $35.7 \%$ (see figure 4).

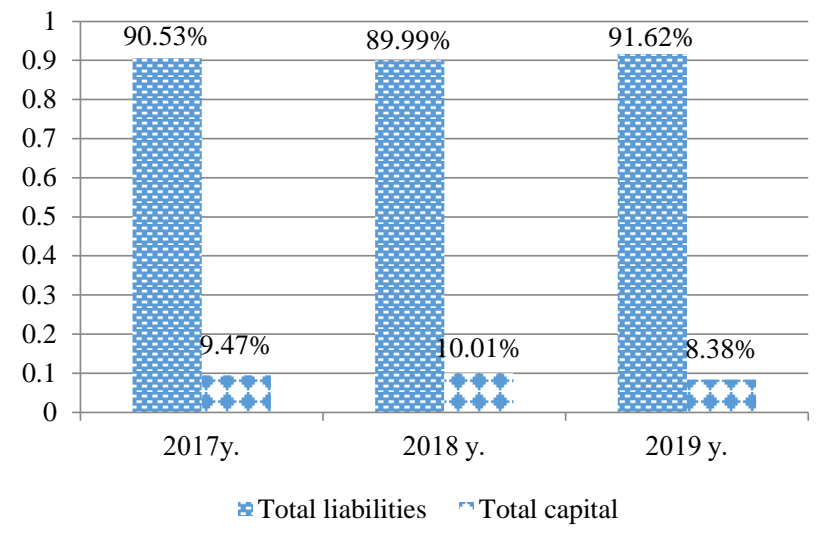

Fig.4. Structure of liabilities and capital, \%

The analysis allows us to conclude the assets and liabilities of JSC "Eurasian Bank":
- the maximum change was made in deposits and Bank accounts decreased by $92.9 \%$, as well as accounts payable under "repo" transactions increased by 15.28 times.

- The share of monetary capital in the deposits of the population and in the Deposit accounts of the Bank's clients was reduced by $-92.9 \%$;

Let's consider the analysis of interest income and interest expenses that characterize the main indicators of the financial results of the Bank under study. Thus, interest income during the study period increases and in 2019 y. reached a value equal to 115.62 billion tenge in comparison with $2017 \mathrm{y}$. increased by 20.44 billion tenge. The increase in this amount was mainly due to loans issued to customers accounted for at amortised cost by 12.75 billion tenge, investments by 1.87 billion tenge, and financial assets by 6.11 billion tenge.

At the same time, interest expenses decreased by 3.66 billion tenge in $2019 \mathrm{y}$. compared to $2017 \mathrm{y}$. Most of the decrease was due to the following indicators: subordinated debt securities by 5.84 billion tenge and accounts payable under repo transactions by 5.06 billion tenge, while debt securities issued increased by 5.79 billion tenge.

Thus, the change in the structure of the Bank's liabilities depends on the financial liabilities measured at fair value. An analysis of the structure of interest expenses and interest income is presented in table 3 .

TABLE III. STRUCTURE AND DYNAMICS OF THE BANK'S PROFIT AND EXPENSES

\begin{tabular}{|c|c|c|c|c|c|c|c|}
\hline \multirow[t]{2}{*}{ Title of article } & $2017 \mathrm{y}$. & 2018 y. & $2019 \mathrm{y}$. & \multirow{2}{*}{ abs. ed. } & $2017 \mathrm{y}$. & 2018 y. & 2019 y. \\
\hline & \multicolumn{3}{|c|}{ billion tenge } & & \multicolumn{3}{|c|}{ Specific weight, \% } \\
\hline Interest income & 95,18 & 83,37 & 115,62 & 20,44 & 100 & 100 & 100 \\
\hline Loans to customers carried at amortised cost & 84,66 & 74,27 & 97,41 & 12,75 & 88,95 & 89,08 & 84,25 \\
\hline Investments carried at amortised cost & 7,38 & 6,38 & 9,25 & 1,87 & 7,75 & 7,65 & 8,00 \\
\hline $\begin{array}{l}\text { Financial assets at fair value through other comprehensive } \\
\text { income }\end{array}$ & 1,02 & 0,90 & 7,13 & 6,11 & 1,07 & 1,08 & 6,17 \\
\hline Accounts receivable under reverse repurchase agreements & 1,94 & 1,64 & 0,37 & $-1,57$ & 2,04 & 1,97 & 0,32 \\
\hline Cash and cash equivalents & 0,15 & 0,15 & 0,24 & 0,09 & 0,15 & 0,18 & 0,21 \\
\hline Bank accounts and deposits & 0,04 & 0,04 & 0,59 & 0,56 & 0,04 & 0,04 & 0,51 \\
\hline Other interest income & & & 0,63 & 0,63 & 0,00 & 0,00 & 0,54 \\
\hline Interest expense & $-61,20$ & $-59,75$ & $-64,87$ & $-3,66$ & 100 & 100 & 100 \\
\hline Current accounts and customer deposits & $-45,28$ & $-43,56$ & $-44,36$ & 0,91 & 73,98 & 72,89 & 68,39 \\
\hline Subordinated debt securities issued & $-4,67$ & $-4,68$ & $-10,52$ & $-5,84$ & 7,64 & 7,84 & 16,21 \\
\hline Accounts payable under repo transactions» & $-0,62$ & $-0,68$ & $-5,68$ & $-5,06$ & 1,01 & 1,13 & 8,75 \\
\hline Debt securities issued & $-8,62$ & $-8,22$ & $-2,83$ & 5,79 & 14,08 & 13,75 & 4,37 \\
\hline Other funds raised & $-2,02$ & $-2,62$ & $-1,47$ & 0,54 & 3,29 & 4,38 & 2,27 \\
\hline Deposits and Bank accounts & 0,00 & 0,00 & 0,00 & 0,00 & 0,01 & 0,01 & 0,01 \\
\hline
\end{tabular}

Based on the data, it can be concluded that one of the key factors that affected the Bank's financial result was a decrease in interest income from loans issued and an increase in expenses on attracted deposits.

Changes in the structure of STB liabilities in the project to reduce the share of interbank loans are explained by a reorientation in the ways of regulating liquidity that deteriorates in the circumstances of inflation in the economy.

The external decrease in liquidity is initially expressed only in a decrease in more realizable assets - currency money, but also in a significant narrowing of the size of attracted liabilities - the interbank market.

In circumstances of inflation, any banking sector makes a strategic decision, sacrificing its liquidity in favor of profit, in order to reduce the loss from the ongoing inflationary depreciation of assets (see figure 4). 
TABLE IV. ANALYSIS OF INTEREST RATES ON LOANS AND DEPOSITS

\begin{tabular}{|c|c|c|c|c|}
\hline & \multirow[t]{2}{*}{ Term } & \multicolumn{3}{|c|}{ Average annual rate, $\%$} \\
\hline & & $2017 y$ & $2018 y$. & $2019 y$. \\
\hline \multirow[t]{2}{*}{ Loans to individuals } & up to 1 year, including "on demand" & 23,8 & 24,02 & 25,99 \\
\hline & over 1 year up & 19,2 & 19,27 & 21,84 \\
\hline \multirow[t]{2}{*}{ Loans to non-financial organizations } & to 1 year & 11 & 12,27 & 15,81 \\
\hline & over 1 year " & 13 & 13,02 & 15,51 \\
\hline \multirow[t]{4}{*}{ Deposits of individuals } & on demand" up & 2,4 & 2,72 & 2,92 \\
\hline & to 1 year without "on demand" up & 7,8 & 8,34 & 12,01 \\
\hline & to 1 year & 7,01 & 7,35 & 12,01 \\
\hline & over 1 year up & 8,9 & 9,05 & 12,51 \\
\hline \multirow[t]{2}{*}{ Deposits of non-financial organizations } & to 1 year, including "on demand" & 7,63 & 7,24 & 12,26 \\
\hline & over 1 year & 9,07 & 9,08 & 10,89 \\
\hline
\end{tabular}

The inflationary impact on the assets and liabilities of banks ' balance sheets is manifested both in a numerical decrease in their size and in a qualitative change in their structure. Comparing the dynamics of movement of real interest rates in different sectors of economic activity and changing the structure of the loan portfolio for the period from 2017 to 2019 , it becomes likely to determine the impact of inflation on the development of the structure of assets and liabilities of the Bank under study.

Thus, it should be noted that changes taking place in the structure of liabilities of JSC "Eurasian Bank" are continuously increasing due to the share of customer deposits attracted by the Bank. So in 2019, the indicator of current accounts and deposits of customers reached the value of 95.49 billion tenge or increased by $14.23 \%$ during the study period, and their share in the total amount of liabilities was $75.50 \%$ in 2019 and increased by $1.75 \%$.

These changes indicate an increase in the share of the most stable resources in the liabilities of banks, which leads to an increase in the cost of the resource base. The increase in the share of deposits of the population is accompanied by a decrease in the share of inexpensive resources - the remaining funds in the accounts. Despite the fact that an increase in the share of deposits of individuals and legal entities in liabilities negatively affects the Bank's liquidity, it guarantees an increase in the degree of liquidity of banks and makes it possible to understand the most long-term procedures over time.

Thus, negative results of inflation affecting the composition of assets and liabilities are expressed in a decrease in the size and share of quickly sold liquid assets, as well as in an increase in "expensive" liabilities, an increase in the amount of attracted customer deposits, which leads to a reduction in net profit.

The measures used by banks of different degrees of capitalization are described in table 5.

The groups of banks listed in the table are presented for the conclusion on the Bank's status as a subject object of direct management. The two groups indicated at the beginning are not subject to administrative influence in any way, unlike the other categories.

TABLE V. MEASURES USED BY BANKS OF VARIOUS CAPITALIZATIONS

\begin{tabular}{|c|l|}
\hline \multicolumn{1}{|c|}{ Sign } & \multicolumn{1}{|c|}{ Characteristic } \\
\hline Well and fairly capitalized & Restriction in remuneration to the staff of AUP, and as a result, the capitalization is reduced. \\
\hline Under-capitalized & Planning to restore capitalization within 45 days \\
\hline Significantly under-capitalized & Payment of remuneration is reduced B. planning to restore capitalization within 45 days \\
\hline Critically under-capitalized & $\begin{array}{l}\text { Termination of operations, in addition to repayment of loans, the Bank is expected to receive Finance. Termination of } \\
\text { interest repayment on loans } 60 \text { days. Complete termination of the operation of a credit institution up to the written } \\
\text { permission of the Supervisory authority }\end{array}$ \\
\hline
\end{tabular}

Banking control organizations examine such characteristics as: the ratio of equity in the Bank's assets combined according to the degree of risk; the ratio of fixed assets in assets, also according to the degree of risk; the ratio of assets weighted average according to the degree of credit risk to total assets. The degree of funds that the correspondent Bank has, when calculating three indicators, indicates the group for which it is necessary to include it.

The system of measures used by Supervisory authorities is intended for a specific indicator of Bank capitalization. A decrease in the Bank's capital level leads to increased control. Commercial banks with sufficient and positive capitalization will not be subject to control and Supervisory measures until the capitalization group changes. Support measures should be applied to poorly capitalized banks.

To improve the Bank's portfolio, reduce the number of unsatisfactory loans, and maintain the mutual trust of potential counterparties, it is necessary to work on the quality of corporate governance. This requires a precise division of direct responsibilities among corporate participants: the meeting of Directors, the team of senior clerks, the Committee of the meeting of Directors for internal control and audit, as well as external audit. 


\section{CONCLUSION}

These measures are presented as a result of the Bank's credit policy. The combined risks of inflation for all banks guarantee the need to include certain factors in the credit policy.

1. inflationary phenomena establish a short-term view of the strategic development of the banking sector, as well as the formation of the banking portfolio based on forecast modeling, therefore, the implementation stage will be approximately 6-12 months;

2.in order to eliminate and minimize banking risks, it is necessary to reduce the amount of lending to individuals, as well as increase the scale of lending to corporate clients with strict collateral. In addition, these measures will make it possible to reduce the risk of deterioration in the quality of the loan portfolio.

3. when examining the Bank's loan portfolio, it is allowed to establish a regulatory measure for establishing a part of loans in foreign monetary units as part of the loan portfolio. In this regard, there may be a weakening of the effects of inflation in the economy, as well as a reduction in interest rates.

The key to success in conducting banking business is a prompt response to inflationary manifestations by updating the long-term strategy and tactics for conducting credit policy.

To prevent growing risks during the period of inflation, it is necessary to focus the asset composition on increasing part of short-term commercial investments in Finance.

However, in order to avoid complete interdependence with the market mechanism, a certain balance should be maintained between investments in real production and shortterm investments. In this case, it is possible to exclude depreciation caused by inflation and interest rate risks, which will make it possible to create a currency portfolio.

\section{REFERENCES}

[1] Annual reports for the period from 2017 to 2019 of Eurasian Bank JSC. Electronic resource. https://eubank.kz/about/for-investors/\#annualreports/(accessed 19.10.2020).

[2] M.V. Antonova, I.V. Chistnikova, and V.V. Mishenin, "Multi-criteria assessment of the optimality of the bank's attracted resources portfolio. Economics. Information technologies" 2020, 47 (2), pp. 328-337. DOI: $10.18413 / 2687-0932-2020-47-2-328-337$

[3] I.V. Chistnikova, M.V. Antonova, E.G. Serova, I.A. Skliarenko, and E.S. Alekhina, "Economic mechanism of functioning of the production system based on the use of lean technologies", Revista inclusiones, 2020, Volumen 7, Número Especial, Octubre-Diciembre, pp. 13-28.

[4] Y. Dosmagambet, Y. Oskenbayev, F. Taghizadeh-Hesary, and M. Mukan, "Financial system, and SME financing in Kazakhstan", ADBI Working Paper Series, 2018, p. 904.

[5] O.G. Kovalenko, "Bank financial management and problems of effective management", Science vector of Togliatti State University. Series: Economics and Management, 2013, 1 (12), pp. 70-72.

[6] W.A. Khan, M. Shahid, R. Bari, W. Anam, N. Shehzad, and S. Siddique, "Impacts of inflationary trends on banks' performance (large banks segment) in Pakistan", International Journal of Accounting and Financial Reporting, 2014, T. 4, 1, p. 296.

[7] G. Kodasheva, et al. "Actual problems of development of the banking sector in the economy of Kazakhstan", Banks \& bank system, 2017, 3 , pp. 257-268.

[8] S. Kumbhakar, and A. Peresetsky, "Cost efficiency of Kazakhstan and Russian banks: results from competing panel data models",
Macroeconomics and Finance in Emerging Market Economies, 2013, 6 (1), pp. 88-113.

[9] O.I. Lavrushin, M : Jurist, Management of the activities of a commercial bank (bank management), 2013, 688 p.

[10] I. Mustafayeva, Z. Huseyn, N. Gurbanov, E. Druzhnikova, Ya. Mochalova, and I. Chistnikova, "The development of management innovation through the use of lean-technology", 37th International Scientific Conference on Economic and Social Development - Socio Economic Problems of Sustainable Development, Baku, Azerbaijan. 14-15 feb, 2019, pp. 505-511.

[11] On the National Bank of the Republic of Kazakhstan, Law of the Republic of Kazakhstan, March 30, 1995, No. 2155.

[12] On banks and banking activities in the Republic of Kazakhstan, Law of the Republic of Kazakhstan dated August 31, 1995, No. 244

[13] On currency regulation and currency control, Law of the Republic of Kazakhstan dated July 2, 2018, No. 167-VI.

[14] N. Orazalin, Corporate governance and corporate social responsibility (CSR) disclosure in an emerging economy: evidence from commercial banks of Kazakhstan, Corporate Governance: The International Journal of Business in Society, 2019.

[15] M.A. Pomorina, The main elements of banking planning: strategy, business planning, financial planning, Banking, 2012, No. 11.

[16] V.M. Soskin, Modern Commercial Bank: Management and Operations, Moscow: IPC "Vazar - Ferro", 2014.

[17] E.A. Stryabkova, I.V. Chistnikova, J.V. Lyshchikova, T.N. Dobrodomova, Ya.V. Mochalova, and A.A. Izvarin, "Human capital as a strategic factor in the development of the region's economy", Herald NAMSCA, 2018, vol. 5, 15 (2), pp. 1128-1133. 